\title{
Pilot-scale production and optimizing of cellulolytic Penicillium oxalicum for controlling of mango malformation
}

\author{
Wafaa M. Haggag ${ }^{1^{*}}$, Mostafa Abo El Soud ${ }^{2}$ \\ ${ }^{1}$ Department of Plant Pathology, National Research Center, Cairo, Egypt; *Corresponding Author: wafaa haggag@yahoo.com \\ ${ }^{2}$ Biotechnology and Genetic Engineering Unit, National Research Center, Cairo, Egypt \\ Received 22 February 2013; revised 26 March 2013; accepted 10 April 2013 \\ Copyright (C) 2013 Wafaa M. Haggag, Mostafa Abo El Soud. This is an open access article distributed under the Creative Commons \\ Attribution License, which permits unrestricted use, distribution, and reproduction in any medium, provided the original work is \\ properly cited.
}

\begin{abstract}
Penicillium oxalicum Curie et Thom isolated from blossom of mango (var. Saddekia) was evaluated against mango malformation incited by Fusarium subglutinis. Both in vitro and in vivo conditions. The mechanism of this isolate for controlling Fusarium was the reduction of growth development. The Penicillium oxalicum isolate produced extracellular cellulolytic enzymes (exoglucanase or cellobiohydrolases and endo-glucanase, that possibly related to the biocontrol process. Optimize and fermentation conditions (growth period, carbon and nitrogen sources) for spores and cellulolytic enzymes production were determined. Liquid formulation containing $(6 \times$ $10^{6}$ ) with sodium alginate $(0.5 \%)$ and Tween 80 $(0.01 \%)$ was used. For field evaluation, susceptible cultivars as Ewais, Saddika, Alphonso, Taimour and Zebda were selected. Liquid bioformulations were sprayed twice and $\mathbf{3 0}$ days intervals. The spray was initiated from pre-flowering stage. Bioformulation was found to be significant in reducing the malformation incidence. Results cleared that spraying of liquid bioformulations, substantially improved the fruit numbers and yield for the five mango cultivars and suggested to be most promotive for fairly quality in tested cultivars.
\end{abstract}

Keywords: Antagonist; Biocontrol; Fusarium subglutinis; Mango Malformation; Penicillium oxalicum

\section{INTRODUCTION}

Mango (Mangifera indica L.) cultivation is an impor- tant agribusiness in Egypt. Even though it has the largest area, the productivity is very low due to various biotic and abiotic strains Haggag Wafaa [1]. Of them, mangoes malformation is the most notorious malady amongst the animate problems affecting both vegetative and floral parts of mango [2,3]. In affected panicles, primary and secondary axes are shortened which result in fruit abortion or no fruit setting [4]. Malformation is noticed on seedlings and saplings organs. Vegetative malformation is most serious on seedlings and small plants in nurseries, especially where seedlings are grown beneath affected trees, a common practice in the Middle East [5,6]. Vegetative malformation also occurs on mature trees. Apical and axillary buds produce misshapen shoots with shortened internodes and dwarfed leaves that are brittle and recurve towards the supporting stem. Shoots may not expand fully; resulting in bunched appearance, (i.e. the "bunchy-top" symptom of the disease. Malformation is the most threatening disease causing colossal losses in yield every year [3] mangos are grown and causes the most severe damage in Egypt [3,5]. The disease has been reduced to insignificant levels in India, Israel, and South Africa simply by removing affected shoots once flower development allows the distinction of malformed and non malformed panicles. After the second or third year, malformation will be reduced to very low levels [5]. The frequency of fungicide application per season has ranged from one to sixteen sprays depending on the mango grower. In recent years, occasional reports from growers have indicated that the control efficacy of the fungicide seems to have dwindled and concerns regarding resistance of the pathogen to the fungicide have been increasing. Biological control of plant pathogens could reduce or eliminate some of those concerns. It is also potentially more effective and much cheaper [7]. Penicilium oxalicum Currie \& Thom is a promising fungal 
agent for biological control of soilborne diseases of tomato [8]. Application of a conidial suspension of $P$. $o x-$ alicum by watering the tomato seedlings in seedbeds 7 days before transplanting usually results in a significant reduction of Fusarium and Verticillium wilts of tomato plants [9]. Species of Penicillium are versatile organisms and have long been known as producers of a wide variety of extracellular enzymes, some of which are of industrial interest such as cellulose and xylans [10]. These enzymes are capable of degrading components that are normally present in other species of fungi. One of the most interesting aspects of these enzymes is their ability to degrade components of fungi that produce diseases in plants and crops. Because the skeleton of filamentous pathogenic fungi cell walls contains chitin, glucan and proteins, the enzymes that hydrolyze these components can successfully antagonize growth of the pathogen. Therefore, a fungus that is able to produce and secrete such enzymes can be envisioned as a natural pesticide. This type of agents is known as biocontrol agents. The successful use of such agents could reduce pollution produced by chemical pesticides.

This study was conducted in order to develop economically and environmentally effective control strategies of mango malformation caused by Fusarium subglutinis through: 1) developing indigenous antagonistic of Penicillium oxalicum; 2) as well as the optimal conditions for antimicrobial formation, production; and 3) control mango malformation disease in vitro and in vivo.

\section{MATERIALS AND METHODS}

\subsection{Isolation of Fungi}

P. oxalicum was isolated from blossom of mango using potato dextrose agar (PDA) (Difco Laboratories, Detroit) and stored on potato dextrose agar (PDA) slants at $4^{\circ} \mathrm{C}$. Fresh conidia obtained after incubation were concentrated and resuspended in sterile distilled water for 10 min, and numbers of conidia were estimated with a hemacytometer.

Isolation of the pathogen from Seddekia mango blossom with malformation symptom was performed by tissue transplanting technique as described above using potato dextrose agar (PDA).

\subsection{Inhibition of Fusarium subglutinis in Vitro}

Five-day-old culture of $F$. subglutinis. (virulent isolate) on PDA and 5-day-old fungus antagonists on PDA was used in this experiment. A mycelial plug of F. subglutinis was cut from colony margin by a $0.8 \mathrm{~cm}$ in diameter cork borer and placed onto the center of a Petri dish containing PDA. Two days after pathogen transfer, a tested fungus isolate was transferred to the dish at four spots in a cross manner, each spot was $3 \mathrm{~cm}$ away from the center of the pathogen' plug. The dish was sealed with a plastic wrap and incubated at room temperature for 3 days. Percent inhibition of mycelial growth of F. subglutinis was recorded daily.

\subsection{In Vitro, Antifungal Activities of the Cell-Free Supernatants of Penicillium oxalicum against Fusarium subglutinis Development}

Fusarium subglutinis was inoculated in $250 \mathrm{ml}$ flasks contained $50 \mathrm{ml}$ of each specific medium and incubated at $30^{\circ} \mathrm{C}$ for 10 days with continuous shaking conditions. Colonized media were filtrated through sterilized membrane (through a $0.45 \mu \mathrm{m}$-pore-size membrane) and then centrifuged a 10,000 rpm for 20 minutes. The clear supernatants were used for the following test. The antifungal activities of cell-free supernatants of biocontrol agent against pathogenic fungi had been carried out by using diffusion method. The potato dextrose yeast agar seeded with test pathogens $(9 \mathrm{~mm})$ were used [11]. The response was observed as a clear zone $(\mathrm{mm})$ around the paper discs (diameter $0.5 \mathrm{~mm}$ ) loaded with concentration of active compound $(20 \mu \mathrm{l})$ were spotted on paper discs. Five plates without any culture filtrate were used as control and incubated at $26^{\circ} \mathrm{C}$.

The conidia of the pathogen used in the study were harvested separately by flooding with sterile water and scrapping the culture with a glass rod.

\subsection{Enzyme Assays}

Endo-glucanase (CMC-ase) and exoglucanase activities were Determined as described previously [12]. For endoglucanase, the total reaction mixture of $3 \mathrm{ml}$ contained $1 \mathrm{ml}$ of carboxymethyl cellulose $\mathrm{Na}$ salt (CMC, $1 \% \mathrm{w} / \mathrm{v}) 1 \mathrm{ml}$ phosphate citrate buffer $(50 \mathrm{mM} \mathrm{pH} \mathrm{7)}$ and $1 \mathrm{ml}$ of appropriately diluted enzyme. After incubation for $30 \mathrm{~min}$ at $40^{\circ} \mathrm{C}$, the reducing sugars were estimated as glucose equivalent by the dinitrosalicyclic acid (DNS) method [13]. Filter paper (FP-ase) activity was determined under similar conditions as described above except that $6 \times 1 \mathrm{~cm}$ What man No. 1 filter paper was used as a substrate in place of CMC.

\subsection{Production Conditions}

\subsubsection{Incubation Period}

The optimization of composition of incubation period, and cultural conditions was carried out based on stepwise modification of the governing parameters for antifungal production. The cultures were transferred to seed broth (200 $\mathrm{mL}$ of Medium) contained in a $500 \mathrm{~mL}$ Erlenmeyer flask and incubated at $30^{\circ} \mathrm{C}$ on a rotary shaker $(175 \mathrm{rpm})$ for 6 - 8 hours. A $500 \mathrm{~mL}$ Erlenmeyer flask containing 
$200 \mathrm{~mL}$ of the same seed medium was incubated as specified above. The seed culture was transferred to a 5 liter fermenter containing each one 3.5 liter of the three liquid media.

\subsubsection{Assay in Liquid Cultures}

Bioagent growth was estimated directly by spectrophotometric measurement of the OD600 $\left(\mathrm{A}_{\max }\right)$ using a PM 2A spectrophotometer and dry biomass concentration $\left(\mathrm{b}_{\max }\right)$. Changing the $\mathrm{pH} 3$ to 10 in the production medium the effect of $\mathrm{pH}$ was observed. The effect of cultivation temperature on the antifungal production was examined at different temperatures starting from $25^{\circ} \mathrm{C}$ to $60^{\circ} \mathrm{C}$ with $5^{\circ} \mathrm{C}$ intervals.

\subsubsection{Determination of Biomass by Cell Dry Weight}

The cells from inoculated flasks, each containing $50 \mathrm{ml}$ fermentation medium, were centrifuged using a cooling centrifuge (Biofuge. Primo R) Heraeus-Germany) in preweighted centrifugation tubes of $50 \mathrm{ml}$ volume (Falcon USA) at $6000 \mathrm{rpm}$ for 10 minutes. The cell precipitates were collected, washed with sterile $0.9 \%$ saline solution and re-centrifuged. The supernatants were discarded and the centrifugation tubes were dried in an oven (Drying oven LabTech LDO-080F, Korea) at $100^{\circ} \mathrm{C}$ till constant weights were obtained. The weight of the dried cells was measured by calculation of the difference between the weight of centrifugation tubes before and after dryness.

\subsubsection{Studying the Time Course of Cellulolytic Enzymes Production by Isolate in Medium under Shaking Condition}

Erlenmeyer flasks containing the previously mentioned medium were prepared, inoculated and incubated as described above. Over an incubation period of 7 days, one flask was removed every $8 \mathrm{~h}$, determination of biomass (optical density and dry weight), residual substrate, inhibition zone and metabolites products.

\subsubsection{Effect of Different Carbon Sources}

The effect of replacing glucose in the cultivated medium with other tested carbon sources on antibiotic production was investigated in Bacillus isolate. The tested carbon source was added at a concentration equivalent in carbon content to that of glucose $(10 \mathrm{~g} / \mathrm{L})$. The tested carbon sources were (D-glucose, D-fructose, sucrose, galactose, Starch, Cellulose, treated molasses and none treated). Erlenmeyer flasks $(250 \mathrm{ml})$ containing $50 \mathrm{ml}$ of the medium devoid of its own carbon source and containing the equivalent amount of other carbon sources were prepared, inoculated and incubated as described in descrybed above. At the end of the incubation period, samples were removed for determination of biomass (op- tical density and dry weight), residual substrate and inhibition zone.

\subsubsection{Effect of Variable Concentrations of the Selected Carbon Source}

Flasks $(250 \mathrm{ml})$ with $50 \mathrm{ml}$ aliquots of the medium containing different concentrations of the carbon source that showed promising results were prepared. These carbon source was surose $(5-30 \mathrm{~g} / \mathrm{L})$. The flasks were terminally sterilized, inoculated and incubated as descrybed above. At the end of the incubation period, samples were removed for determination of biomass (optical density and dry weight), residual substrate and inhibition zone.

\subsubsection{Effect of Different Nitrogen Sources}

This was studied by replacing sodium nitrate of medium with other tested nitrogen sources. The tested nitrogen source was added at a concentration equivalent in nitrogen content to that of sodium nitrate $(2.5 \mathrm{~g} / \mathrm{L})$. The nitrogen sours were Peptone + yeast extract; Pepton + trypton; Peptone + soyabean; Yeast extract + trypton; Yeast extract + soyabean; Trypton + soyabean; Soyabean + trypton; Pepton; Yeast extract; Trypton; Soyabean. In case of urea, a stock solution was prepared; filter sterilized $(0.22 \mu \mathrm{m})$ and then an aliquot containing the required amount of urea was incorporated aseptically. At the end of the incubation period, samples were removed for determination of biomass (optical density and dry weight), residual substrate and inhibition zone.

\subsubsection{Field Application}

To determine the efficacy of culture filtrate of Penicillium oxalicum on mango malformation disease, two field experiments were conducted, using the susceptible cultivars Awais (10 yr-old) and Saddekia (10 yr-old) at Noubaria region, Behera Governorate and Ismailia Governorate in 2010 season and five cultivars at Ismailia Governorate in 2011 season. Treatment was applied twice at 20d intervals starting from February 15 (about one month before normal flowering) on mango trees in one year. Liquid formulation was prepared using $0.01 \%$ of methylcellulose and tween 80. Liquid formulation of $P$. oxalicum was sprayed by using a knapsack sprayer. Trees were sprayed till run-off with approximately $10 \mathrm{~L}$ of spray solution per tree. Treatments were assigned in a randomized complete block design. Trees sprayed with water served as a check treatment. Plots consisting of three mango trees were replicated three times. Irrigation, fertilization and other cultural practices were carried out as recommended. The percentages of diseases incidence were arcsin transformed before analysis of variance to improve homogeneity of variance. The average yield per tree in $\mathrm{kg}$ per treatment was determined at harvest stage. 


\subsubsection{Statistical Analysis}

The collected data were evaluated statistically using the software spss for Windows (release 7.5.1, 20 December 1996; SPSS Inc., Chicago, IL).

\section{RESULT}

\subsection{Inhibition of Fusarium moniliforme in Vitro}

Penicillium oxalicum was tested against Fusarium pathogen. Penicillium was highly effective that inhibiting the mycelial growth. The isolate exhibited the maximum pathogen suppression (59 percent) and completely upto tenth day (Figure 1).

In vitro, the efficacy of filtrate of Penicillium oxalicum against $F$. moniliforme development, i.e. mycelium growth, is showed in Table 1. In most cases, metabolite of Penicillium oxalicum showed antifungal activity against Fusarium pathogen growth expressed as zone inhibition. The conidial germination was recorded at different intervals upto $24 \mathrm{~h}$ after. The data show that filtrate extract tested significantly reduced the conidial germination over control.

\subsection{Activity, Purification and Molecular Weight of Native CMCase and $\beta-1,3$ Glucanse from $P$. oxalicum}

Enzyme specific activity is shown in Figure 2. Results showed that in optimize conditions, $P$. oxalicum has highest CMcase $(11.4 \mathrm{u} / \mathrm{mg})$ and $\beta-1,3$ glucanse (4.32 $\mathrm{u} / \mathrm{mg}$ ) enzymes specific activities (Figure 2). To purify the enzyme, fungus spores were incubated in broth culture containing $0.5 \%(\mathrm{w} / \mathrm{v}) \mathrm{CMC}$ as carbon source to induce the synthesis of the enzymes. The molecular weight of the purified enzyme analysed by SDS-PAGE and stained with Coomassie Brilliant Blue showed a single band of approximately 80 and $85 \mathrm{kDa}$ (Figure 3) corresponding to the CMCase and endo $\beta-1,3$ glucanase enzymes based on its high activity on substrates, respectively.

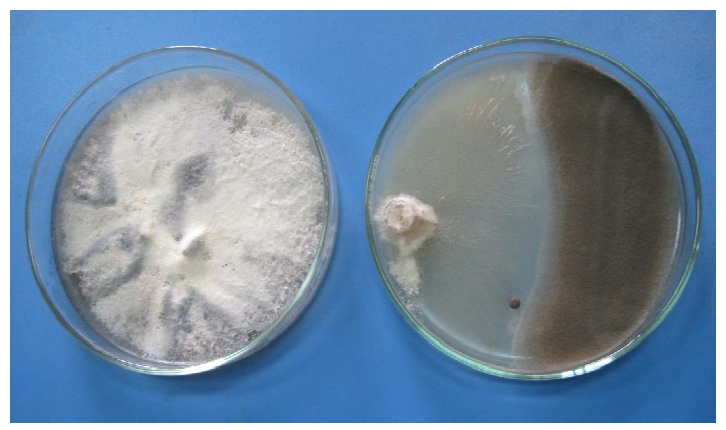

Figure 1. Antifungal activity of Penicillium oxalicum against Fusarium subglutinis.

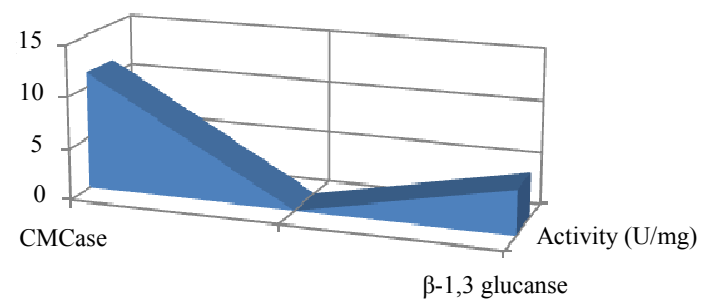

Figure 2. Production of extracellular exo-glucanase and $\beta-1,4$ endoglucanase (CMCase) in shake flasks.
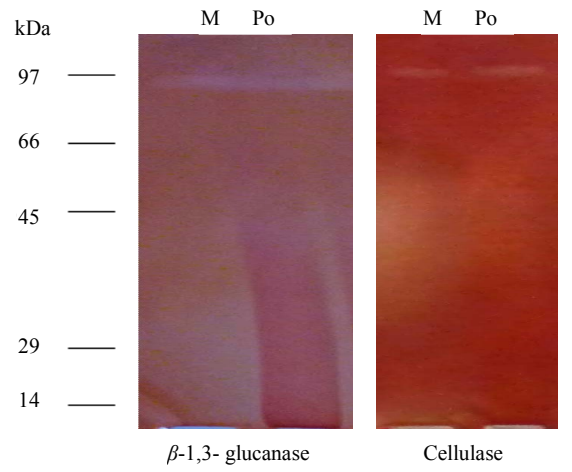

Figure 3. 12\% SDS-PAGE of exo-glucanase and crude CMCase ad for determination of molecular weight.

Table 1. Antifungal activity of Penicillium oxalicum filtrate against Fusarium subglutinis.

\begin{tabular}{ccc}
\hline \multirow{2}{*}{$\begin{array}{c}\text { Filtrate } \\
\text { Concentration \% }\end{array}$} & \multicolumn{2}{c}{ Purified active substance } \\
\cline { 2 - 3 } & Inhibition zone $(\mathrm{cm})$ & $\begin{array}{c}\text { Reduction of spore } \\
\text { germination \% }\end{array}$ \\
\hline 25 & $2.49^{\mathrm{c}}$ & $88.9^{\mathrm{b}}$ \\
50 & $2.55^{\mathrm{b}}$ & $91.7^{\mathrm{ab}}$ \\
75 & $2.73^{\mathrm{ab}}$ & $91.5^{\mathrm{ab}}$ \\
100 & $2.85^{\mathrm{a}}$ & $92.4^{\mathrm{a}}$ \\
\hline
\end{tabular}

Values represent the mean percentage of six replicates. Values in each column followed by the same letter are not significantly different $(\mathrm{P}<0.05)$.

\subsection{Optimization Condition for Antifungal Metabolite Production}

The kinetic profile of cell mass and cellulase production by $P$. oxalicum grown in different media and growth period was illustrated in Figures $\mathbf{4}$ and $\mathbf{5}$. The $\mathrm{pH}$ profile shows that the value decreases with time to 4.2 after 50 hrs then starts increasing again during the rest of incubation time. Dry weight increases with time until it reaches its maximum at $72 \mathrm{hrs}$ then decreases slightly with time (Figure 4). In the inhibition zone curve, F. subglutins follow the same pattern whereas the inhibition zone increases with incubation period till $90 \mathrm{hrs}$ then starts to decrease. Analysis of cellulase activity indicates that the production of the enzyme is significantly influenced $(\mathrm{P}<$ 0.001 ) by the growth period, that increases with time 

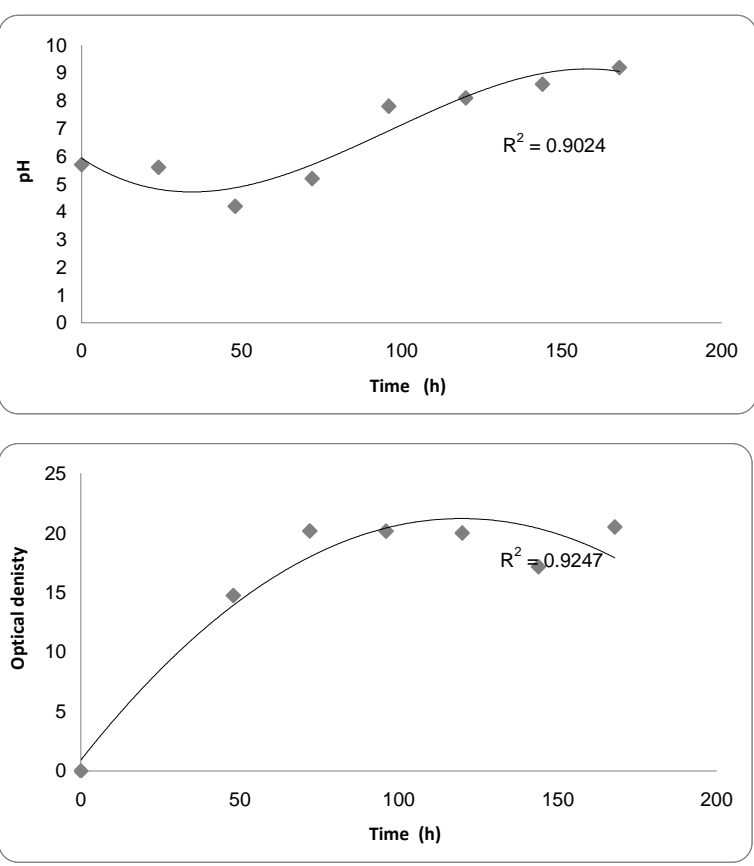

Figure 4. Effect of different incubation time on the growth, inhibition activity and production of antifungal of $P$. oxallicum.

until it reaches its maximum at $90 \mathrm{hrs}$ then decreases slightly with time. Analysis of $\beta-1,3$ glucanase activity indicates that the production of the enzyme is significantly influenced $(\mathrm{P}<0.001)$ by the growth period. $\beta-1,3$ glucanase activity also increases with time until it reaches its maximum at $90 \mathrm{hrs}$ then decreases slightly with time. The maximum incubation period for the growth of Penecillium is $50 \mathrm{hrs}$ (Figure 5).

\subsection{Effect of Various Carbon Sources on Mass and Cellulase Production}

For the growth of microorganism carbon source is the very essential with other nutrient sources, etc. Various carbon sources included D-glucose, D-fructose, sucrose, galactose, Starch, Cellulose were examined. From the experimental results it was noticed that by using different types of carbon source, the biomass growth was maximum with sucrose as substreate. Also, the zone inhibition $(\mathrm{mm})$ and cellulose were maximum after $72 \mathrm{~h}$ incubation with sucrose as a carbon source (Figure 6). So, the sucrose was chosen as an optimum carbon source for $P$. oxalicum. By using different concentration of sucrose for the growth of $P$. oxalicum, $\mathrm{pH}$ was maximum at $5 \mathrm{~g} / 1$ sucrose after $72 \mathrm{~h}$ and minmum at $25 \mathrm{~g} / 1$ sucrose concentration (Figure 7). The dry weight concentration increased with increasing the sucrose concentration. Also, the production of cellulase increased by increasing the sucrose concentration till $20 \mathrm{~g} / 1$ then decreased again. The zone inhibition increased gradually by increasing the
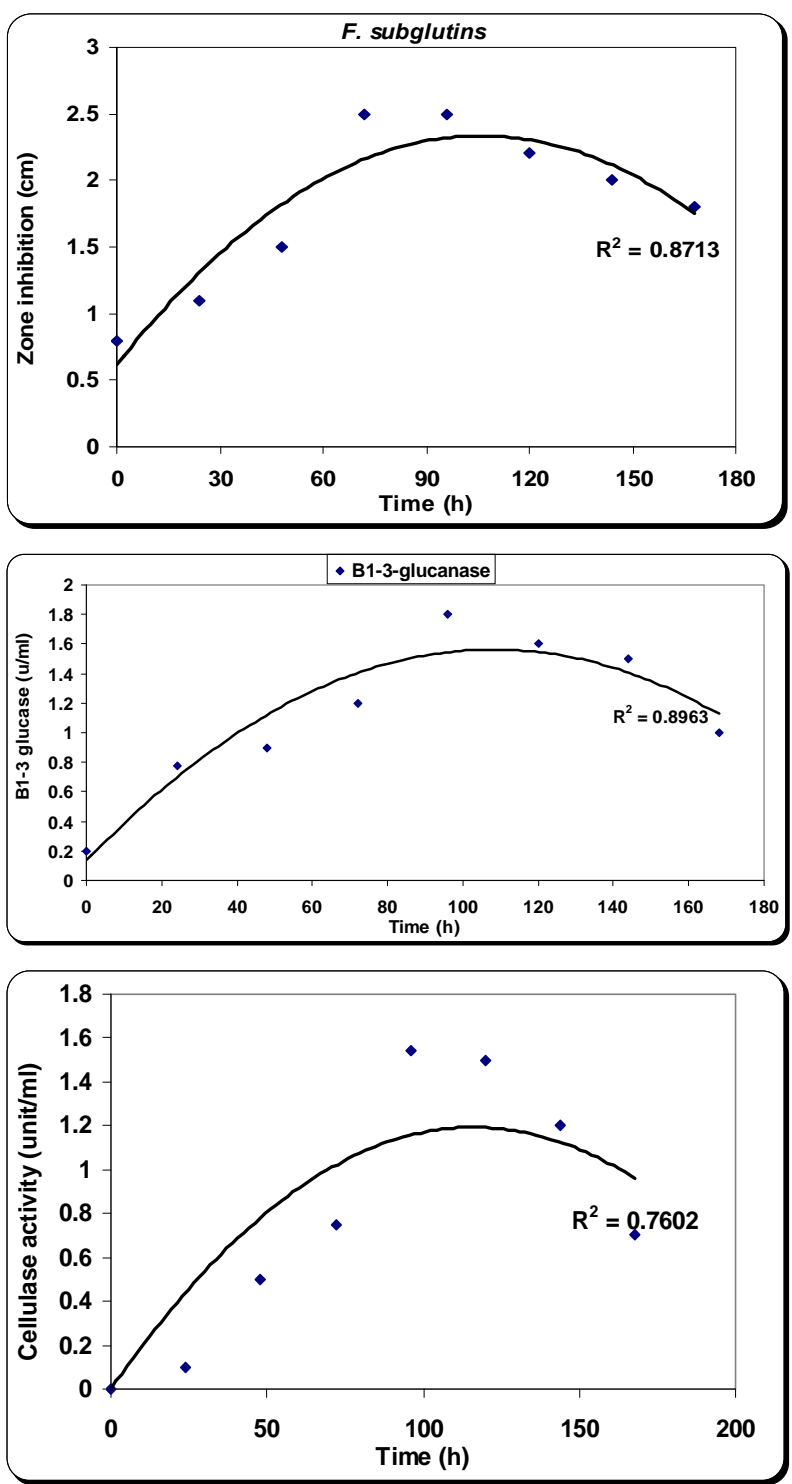

Figure 5. Effect of different incubation time on the growth, inhibition activity and production of antifungal of $P$. oxallicum.

sucrose concentration till $20 \mathrm{~g} / \mathrm{l}$ then remained constant. (Figure 7). From the previous observations, $20 \mathrm{~g} / \mathrm{l}$ was chosen as the optimum sucrose concentration.

\subsection{Effect of Various Nitrogen Sources on Mass and Cellulase Production}

Nitrogen sources are very important for the microbial growth and to maximize the final reaction product next to carbon sources. For nitrogen sources the medium was supplemented with peptone, yeast extract, potassium dihydrogen phosphate, ammonium sulphate and ammonium chloride in equivalent concentrations to the production medium. By using different types of nitrogen source for the growth of P. oxalicum it was noticed that the maximum biomass growth, $\mathrm{pH}$, zone inhibition and 

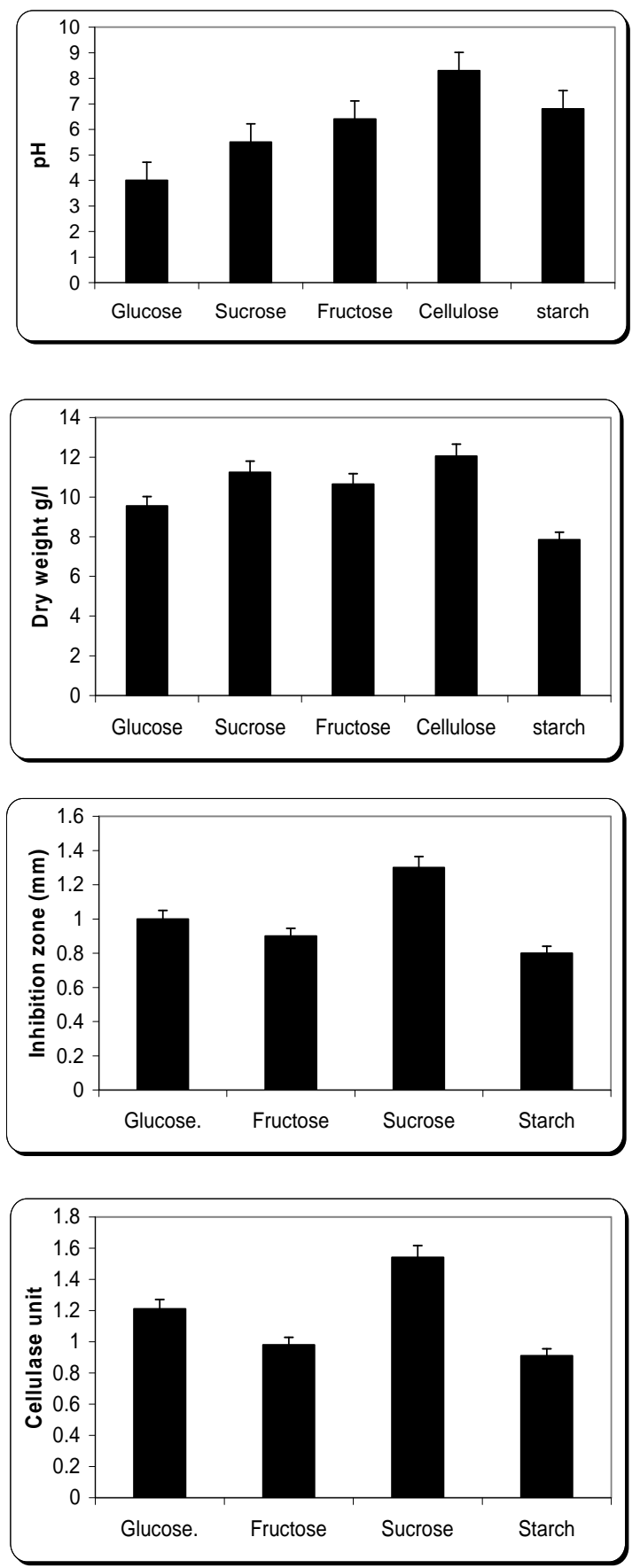

Figure 6. Effect of different carbon source on the growth, inhibition activity and production of antifungal of $P$. oxallicum.

cellulose were obtained with yeast extract and soyabean in equal ratio in the media (Figure 8). So, the optimum nitrogen source chosen was an equal ratio of yeast extract and soyabean (Figure 8).

\subsection{Field Experiment}

The efficacies of the liquid formulation of $P$. oxallicum
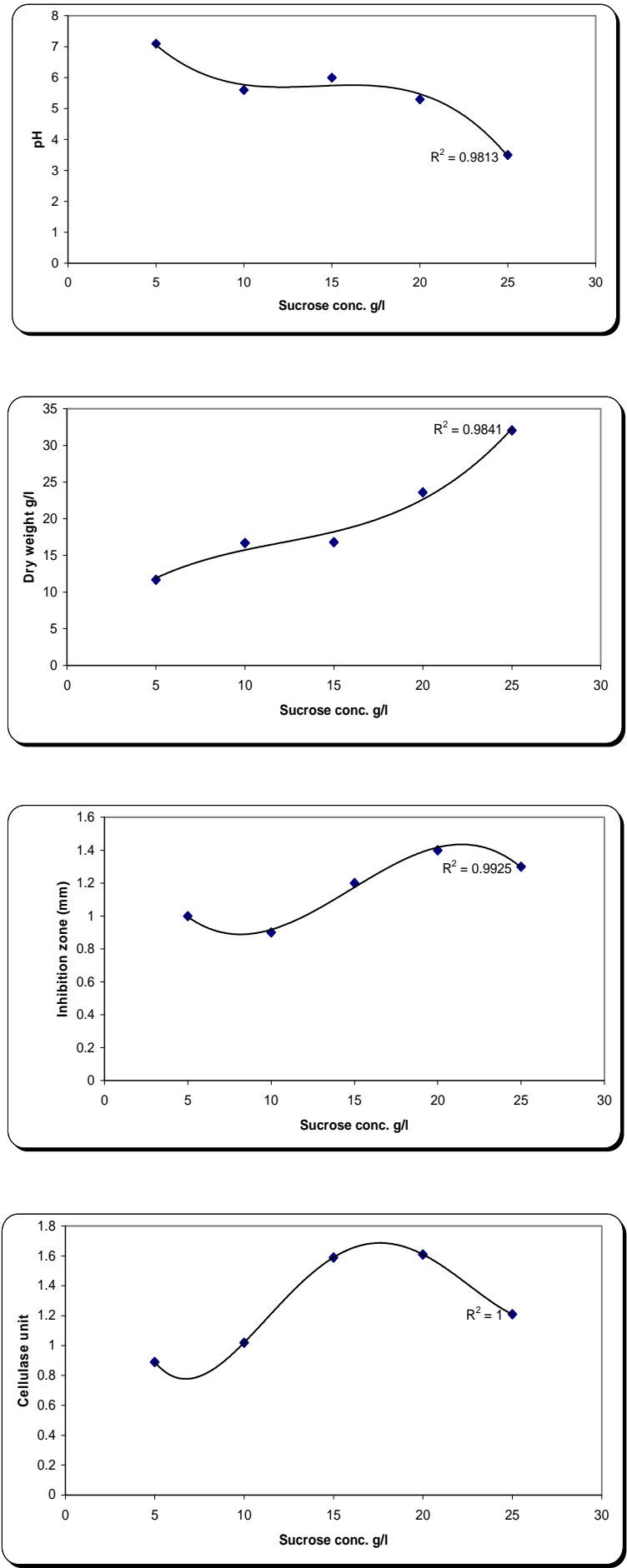

Figure 7. Effect of carbon concentrations on the growth, inhibition activity and production of antifungal of $P$. oxallicum.

against malformation disease caused by Fusarium subglutinis of mango under natural conditions were determined in seasons of 2010 using Seddekia and Ewais cultivars in Boheara and Ismailia governorates in 2010 and applied in large scale during 2011 season using local 

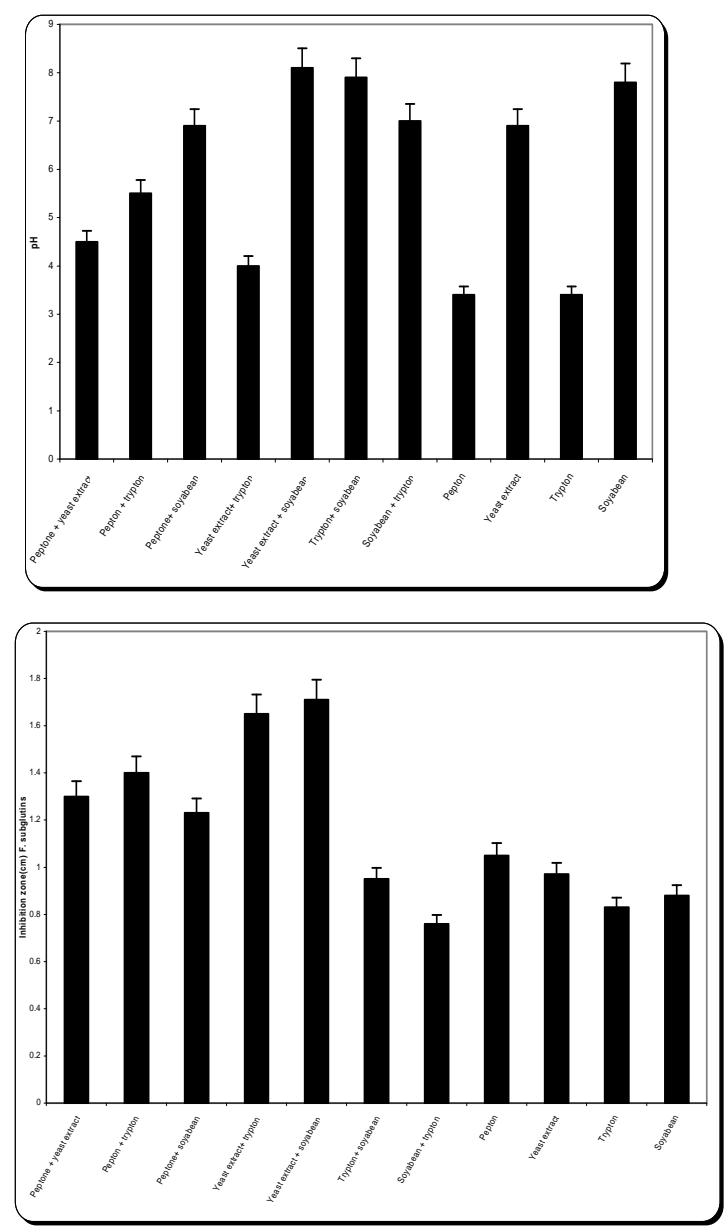
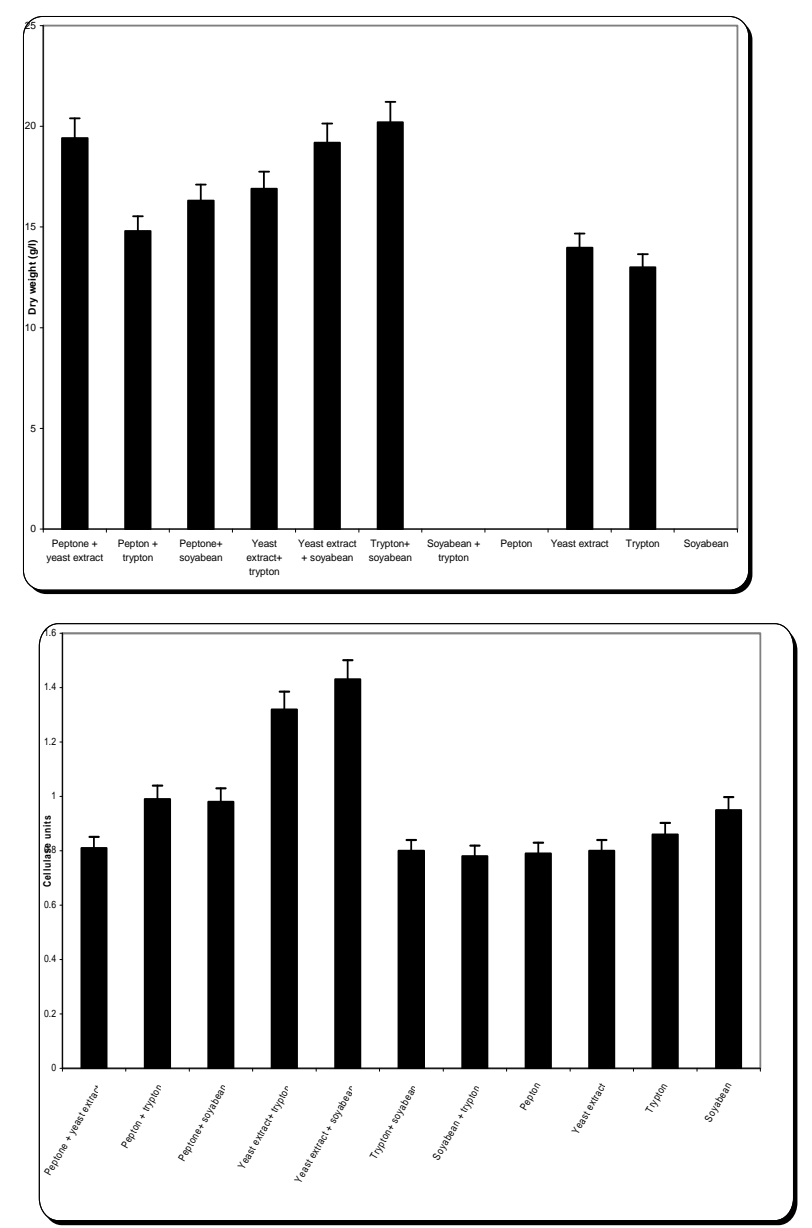

Figure 8. Effect of different nitrogen source on the growth, inhibition activity and production of antifungal of $P$. oxallicum.

and exotic cultivars in Ismailia governorate. Cultivars Ewais, Seddekia and Alphonso were most susceptible to infection. The percentage of malformation disease incidence on mango vegetative buds and flowers blossom clusters obtained by the liquid formulation of $P$. oxallicum treatment compared to the control and fungicide (Tobseen) is shown in Tables 2 and 3. The disease incidence of malformation was substantially higher on flowers blossom clusters than in vegetative buds in untreated control. Significant reduction of disease incidence was achieved by applying of liquid formulation of $P$. oxallicum compared to the untreated control during growth period in both seasons. The effect of liquid formulation of $P$. oxallicum on fruit yield was determined (Tables 4 and 5). The reduction in yield was observed under disease infection. It is clear that, foliar spray of mango with liquid formulation of $P$. oxallicum has significantly increased the fruit yield compared to untreated control and fungicide. Since, higher increase in fruit yield was obtained when the trees were sprayed with fungicides by $\mathrm{kg} /$ tree in compared with $\mathrm{kg} /$ tree in untreated control and fungicide.

\section{DISCUSSION}

Fusarium malformation of mango is an intractable problem because management strategies such as cultivar resistance and chemical control are not always appropri ate [2-4]. It is not surprising that there is interest in discovering a remedy based on biological control. Several fungicide from chemical residue are presently used for control of mango malformation but this material has toxic effect also the control by this fungicide lead to the resistance of the causal pathogen. Natural products may serve as lead as structures for new safe biological fungicide instate of chemical substance to participate in decreasing environmental pollution. Biological control of plant pathogens could reduce of this concern.

This is the first time that the fungus Penicillium oxalicum is reported as an antagonistic microorganism of the pathogen Fusarium subglutinis the causal organism of mango malformation. Microorganism showed high- ly antifungal activity against Fusarium pathogen. In most cases, both Penicillium oxalicum and its metabolite showed antifungal activity against $F$. moniliforme growth that colonized spores and hyphae when it applied as 
Table 2. Efficacy of foliar sprays of liquid formulation of $P$. oxallicum on the incidence of vegetative buds and flower clusters malformation of mango cultivars under natural infested conditions (season 2010).

\begin{tabular}{|c|c|c|c|c|c|c|c|c|}
\hline \multirow{4}{*}{ Treatment } & \multicolumn{8}{|c|}{ Percentage of disease incidence $\%$} \\
\hline & \multicolumn{4}{|c|}{ Noubaria } & \multicolumn{4}{|c|}{ Ismailia } \\
\hline & \multicolumn{2}{|c|}{ Ewais } & \multicolumn{2}{|c|}{ Saddika } & \multicolumn{2}{|c|}{ Ewais } & \multicolumn{2}{|c|}{ Saddika } \\
\hline & Vegetative & Blossom & Vegetative & Blossom & Vegetative & Blossom & Vegetative & Blossom \\
\hline Control & $50^{\mathrm{a}}$ & $61.3^{\mathrm{a}}$ & $40.6^{\mathrm{a}}$ & $45.5^{\mathrm{a}}$ & $62.6^{\mathrm{a}}$ & $71.0^{\mathrm{a}}$ & $50.7^{\mathrm{a}}$ & $65.5^{\mathrm{a}}$ \\
\hline P. oxallicum & $3.3^{\mathrm{c}}$ & $4.5^{\mathrm{c}}$ & $2.4^{\mathrm{c}}$ & $3.3^{\mathrm{c}}$ & $4.5^{\mathrm{c}}$ & $5.6^{\mathrm{c}}$ & $2.4^{\mathrm{c}}$ & $3.8^{\mathrm{c}}$ \\
\hline Fungicide (Tobseen ) & $30.7^{\mathrm{b}}$ & $37.8^{\mathrm{b}}$ & $22.6^{\mathrm{b}}$ & $29.3^{\mathrm{b}}$ & $39.1^{\mathrm{b}}$ & $47.4^{\mathrm{b}}$ & $22.5^{\mathrm{b}}$ & $29.8^{\mathrm{b}}$ \\
\hline
\end{tabular}

Values represent the mean percentage of six replicates. Values in each column followed by the same letter are not significantly different $(\mathrm{P}<0.05)$.

Table 3. Efficacy of foliar sprays of liquid formulation of $P$. oxallicum on the incidence of vegetative buds and flower clusters malformation of mango cultivars under natural infested conditions (season 2011).

\begin{tabular}{|c|c|c|c|c|c|c|c|c|c|c|}
\hline \multirow{3}{*}{ Treatment } & \multicolumn{10}{|c|}{ Percentage of disease incidence $\%$} \\
\hline & \multicolumn{2}{|c|}{ Ewais } & \multicolumn{2}{|c|}{ Saddika } & \multicolumn{2}{|c|}{ Alphonso } & \multicolumn{2}{|c|}{ Taimour } & \multicolumn{2}{|c|}{ Zebda } \\
\hline & Vegetative & Blossom & Vegetative & Blossom & Vegetative & Blossom & Vegetative & Blossom & Vegetative & Blossom \\
\hline Control & $52.2^{\mathrm{a}}$ & $66.4^{\mathrm{a}}$ & $48.6^{\mathrm{a}}$ & $61.2^{\mathrm{a}}$ & $40.2^{\mathrm{a}}$ & $49.4^{\mathrm{a}}$ & $38.6^{\mathrm{a}}$ & $46.2^{\mathrm{a}}$ & $12.2^{\mathrm{a}}$ & $16.4^{\mathrm{a}}$ \\
\hline P. oxallicum & $2.5^{\mathrm{c}}$ & $3.6^{\mathrm{c}}$ & $2.1^{\mathrm{c}}$ & $3.2^{\mathrm{c}}$ & $1.3^{\mathrm{c}}$ & $2.7^{\mathrm{c}}$ & $1.1^{\mathrm{c}}$ & $2.5^{\mathrm{c}}$ & $0.0^{\mathrm{c}}$ & $0.0^{\mathrm{c}}$ \\
\hline Fungicide (Tobseen) & $33.4^{\mathrm{b}}$ & $43.4^{\mathrm{b}}$ & $20.4^{\mathrm{b}}$ & $25.2^{\mathrm{b}}$ & $24.4^{\mathrm{b}}$ & $22.7^{b}$ & $15.4^{\mathrm{b}}$ & $20.2^{\mathrm{b}}$ & $9.4^{\mathrm{b}}$ & $13.5^{b}$ \\
\hline
\end{tabular}

Values represent the mean percentage of six replicates. Values in each column followed by the same letter are not significantly different $(\mathrm{P}<0.05)$.

Table 4. Efficacy of foliar sprays of liquid formulation of $P$. oxallicum on fruit yield of mango cultivars under natural infested conditions (season 2010)

\begin{tabular}{|c|c|c|c|c|c|c|c|c|}
\hline \multirow{4}{*}{ Treatment } & \multicolumn{8}{|c|}{ Fruit yield/tree } \\
\hline & \multicolumn{8}{|c|}{ Noubaria Ismailia } \\
\hline & \multicolumn{2}{|l|}{ Ewais } & \multicolumn{2}{|c|}{ Saddika } & \multicolumn{2}{|l|}{ Ewais } & \multicolumn{2}{|l|}{ Saddika } \\
\hline & Fruit number/tree & Yield/tree & Fruit number/tree & Yield/tree & Fruit number/tree & Yield/tree & Fruit number/tree & Yield/tree \\
\hline Control & $11.5^{\mathrm{b}}$ & $8.54^{\mathrm{c}}$ & $12.5^{\mathrm{b}}$ & $10.4^{\mathrm{c}}$ & $13.4^{\mathrm{c}}$ & $12.3^{b}$ & $14.3^{\mathrm{c}}$ & $12.4^{\mathrm{b}}$ \\
\hline P. oxallicum & $18.2^{\mathrm{a}}$ & $16.4^{\mathrm{a}}$ & $17.5^{\mathrm{a}}$ & $18.3^{\mathrm{a}}$ & $23.4^{\mathrm{a}}$ & $18.6^{\mathrm{a}}$ & $19.3^{\mathrm{a}}$ & $18.0^{\mathrm{a}}$ \\
\hline Fungicide (Tobseen) & $12.1^{\mathrm{b}}$ & $11.3^{\mathrm{b}}$ & $14.6^{\mathrm{b}}$ & $15.1^{\mathrm{b}}$ & $16.5^{\mathrm{b}}$ & $13.4^{\mathrm{b}}$ & $17.1^{\mathrm{b}}$ & $14.7^{\mathrm{b}}$ \\
\hline
\end{tabular}

Values represent the mean percentage of six replicates. Values in each column followed by the same letter are not significantly different $(\mathrm{P}<0.05)$.

Table 5. Efficacy of foliar sprays of liquid formulation of $P$. oxallicum on fruit yield of mango cultivars under natural infested conditions (season 2010).

\begin{tabular}{|c|c|c|c|c|c|c|c|c|c|c|}
\hline \multirow{4}{*}{$\begin{array}{c}\text { Treatment } \\
\text { Control }\end{array}$} & \multicolumn{10}{|c|}{ Fruit yield/tree } \\
\hline & \multicolumn{4}{|c|}{ Ewais Saddika } & \multicolumn{4}{|c|}{ Alphonso Taimour } & \multicolumn{2}{|c|}{ Zebda } \\
\hline & \multicolumn{2}{|c|}{ Fruit number yield } & \multicolumn{2}{|c|}{ Fruit number yield } & \multicolumn{2}{|c|}{ Fruit number yield } & \multicolumn{2}{|c|}{ Fruit number yield } & \multicolumn{2}{|c|}{ Fruit number yield } \\
\hline & $27.4^{\mathrm{b}}$ & $24.3^{\mathrm{b}}$ & $26.2^{\mathrm{c}}$ & $24.4^{\mathrm{c}}$ & $54.5^{\mathrm{c}}$ & $83.6^{\mathrm{c}}$ & $51.8^{\mathrm{b}}$ & $92.4^{\mathrm{c}}$ & $62.3^{b}$ & $98.6^{\mathrm{c}}$ \\
\hline P. oxallicum & $48.2^{\mathrm{a}}$ & $40.6^{\mathrm{a}}$ & $39.3^{\mathrm{a}}$ & $41.0^{\mathrm{a}}$ & $65.7^{\mathrm{a}}$ & $114.5^{\mathrm{a}}$ & $64.7^{\mathrm{a}}$ & $132.4^{\mathrm{a}}$ & $77.3^{\mathrm{a}}$ & $136.3^{\mathrm{a}}$ \\
\hline Fungicide (Tobseen) & $29.5^{\mathrm{b}}$ & $26.4^{\mathrm{b}}$ & $31.1^{\mathrm{b}}$ & $27.7^{\mathrm{b}}$ & $59.4^{\mathrm{b}}$ & $94.7^{\mathrm{b}}$ & $54.6^{\mathrm{b}}$ & $101.5^{\mathrm{b}}$ & $64.2^{\mathrm{b}}$ & $113.2^{\mathrm{b}}$ \\
\hline
\end{tabular}

Values represent the mean percentage of six replicates. Values in each column followed by the same letter are not significantly different $(\mathrm{P}<0.05)$. 
spores. When purified active substance applied, significantly inhibited pathogen growth expressed as zone inhibition. Mycoparasitism involving lytic enzymes has been already described as the mechanism of action of Penecillium isolates in the biological control of commercially important plant pathogens $[8,10]$. Reports on glucanases, cellulase, and the relative importance of any of these systems in the antagonistic process as antifungal agents are well documented [14]. Thus, the culture filtrate of Penicillium oxalicum was against Fusarium subglutinis the causal organism of mango malformation. Our results show that Penicillium oxalicum produced exo-glucanase or cellobiohydrolases and endo-glucanase when it was grown with all of the carbon sources examined. The level of production of exo-glucanase or cellobiohydrolases and endo-glucanase varied depending on the carbohydrate source, nitrogen sources and incubation period etc. Changes in one of these parameters can have a dramatic effect on the yield of cells and the stability of protein product. The meaning of optimization in this context needs careful consideration of the environmental and nutritional parameters for growth and production. Optimization of fermentation media ingredients and environmental factors for enzyme production is a more convenient and effective strategy, compared to other recent approaches like molecular techniques, to manifest the physiological characteristics to synthesis enzymes. Penicillium species in toxigenic capacity of the secondary substances or metabolites excreted [15]. P. oxalicum has been reported to be a biocontrol agent for Fusarium oxysporum f. sp. lycopersici [16]. Leaf spot severity (Cercospora canescens) on Vigna mungo was reduced by spraying with $P$. oxalicum before inoculation of $C$. canescens [17].

Foliar application of culture filtrate on mango trees provided greater efficacy for controlling malformation disease suggested that the fungus produce some antifungal enzymes. Penicillium oxalicum promising fungus antagonists for controlling mango malformation disease. $P$. oxalicum has shown a good potential for development as a commercial biocontrol product. Nondusty, liquid formulations of $P$. oxalicum culture filtrate developed as biofungicide for controlling mango malformation.

\section{ACKNOWLEDGEMENTS}

This project was supported financially by the Science and Technology Development Fund (STDF), Egypt, Grant No. 216 under title: Development of Bioproducts as Bio-fungicides for Controlling of Major Foliar Diseases of Some Economic Horticultural Crops, from 20092012; P. I. Wafaa M. Haggag.

\section{REFERENCES}

[1] Haggag Wafaa, M. (2010) Mango diseases in Egypt. Ag- riculture and biolog. Journal of North America, 1, 285 289. doi:10.5251/abjna.2010.1.3.285.289

[2] Haggag Wafaa, M., Hazza, M., Sehab, A. and Abd El-Wahab, M. (2010) Scanning electron microcopy studies on mango malformation. Nature and Science, 8, 122-127.

[3] Haggag Wafaa, Hazza, M., Sehab, A. and Abd El-Wahab, M. (2010) Epidemiology and the association of the Fusarium species with the mango malformation disease in Egypt. Nature and Science, 8, 128-135.

[4] Ploetz, R. and Ploetz, R. (2003) Diseases of mango. In: Ploetz, R.C., Ed., Diseases of Tropical Fruit Crops, CAB International, Wallingford, 327-363.

[5] Ploetz, R., Zheng, Q.I., Vázquez, Á. and Sattar, M.A.A. (2002) Current status and impact of mango malformation in Egypt. International Journal of Pest Management, 48, 279-285. doi:10.1080/09670870210149817

[6] Youssef, S.A., Maymon, M., Zveibil, A., Klein-Gueta, D., Sztejnberg, A., Shalaby, A.A. and Freeman, S. (2007) Epidemiological aspects of mango malformation disease caused by Fusarium mangiferae and source of infection in seedlings cultivated in orchards in Egypt. Plant Pathology, 56, 257-263.

doi:10.1111/j.1365-3059.2006.01548.x

[7] Haggag Wafaa, M. and Mohamed, H.A.A. (2007) Biotechnological aspects of microorganisms used in plant biological control. American-Eurasian Journal of Sustainable Agriculture, 1, 7-12.

[8] Sabuquillo, P., De Cal, A. and Melgarejo, P. (2005) Dispersal improvement of a powder formulation of Penicillium oxalicum, a biocontrol agent of tomato wilt. Plant Disease, 89, 1317-1323. doi:10.1094/PD-89-1317

[9] Larena, I., Melgarejo, P. and De Cal, A. (2003) Drying of conidia of Penicillium oxalicum, a biological control agent against Fusarium wilt of tomato. Journal of Phytopathology, 151, 600-606. doi:10.1046/j.0931-1785.2003.00772.x

[10] Hamlyn, P.F., Wales, D.S. and Saga, B.F. (1987) Extracellular enzymes of penicillium. In: Peberdy, J.F., Ed., Penicillium and Acremonium, Plenum Press, New York, 245-284.

[11] Lumsden, R.D., Ridout, C.J., Vendemia, M.E. and Harrison, D.J. (1992) Characterization of major secondary metabolites produced in soilless mix by formulated strain of biocontrol fungus Gliocladium virens. Journal of Plant Physiology, 38, 1274-1280.

[12] Rajoka, M.I. (2004) Influence of various fermentation variables on exo-glucanase production in Cellulomonas flavigena. Electronic Journal of Biotechnology, 7, 256263.

[13] Miller, G.L. (1959) Use of dinitrosalisylic acid (DNS) for determination of reducing sugars. Analytical Chemistry, 31, 426-428. doi:10.1021/ac60147a030

[14] Sanz, L., Montero, M., Redondo, J., Llobell, A. and Monte, E. (2005) Expression of an \{alpha\}-1,3-glucanase during mycoparasitic interaction of Trichoderma asperellum. FEBS Journal, 272, 493-499. doi:10.1111/j.1742-4658.2004.04491.x

[15] Jiménez, M., Sanchis, V., Mateo, R. and Hernández, E. 
(1986) Penicillium in pre-harvest corn in Valencia (Spain) II. Study of the enzymatic and toxigenic capacities of the species. Mycopathologia, 96, 13-18. doi:10.1007/BF00467679

[16] De Cal, A., Pascual, S. and Melgarejo, P. (1997) Involvement of resistance induction by Penicillium oxalicum in the biocontrol of tomato wilt. Plant Pathology, 46, 72-79. doi:10.1046/j.1365-3059.1997.d01-204.x

[17] Rao, P.B. and Mallaiah, K.V. (1988) Effect of phyllophane fungi on the leaf spot pathogen Cercospora canescens. Indian Journal of Microbiology, 28, 103-107. 